\title{
The T-cell anergy induced by Leishmania amazonensis antigens is related with defective antigen presentation and apoptosis
}

\author{
ROBERTA O. PINHEIRO, EDUARDO F. PINTO, ALESSANDRA B. BENEDITO, \\ ULISSES G. LOPES and BARTIRA ROSSI-BERGMANN \\ Instituto de Biofísica Carlos Chagas Filho, Universidade Federal do Rio de Janeiro \\ Cidade Universitária, Ilha do Fundão, 21949-900 Rio de Janeiro, RJ, Brasil \\ Manuscript received on September 22, 2003; accepted for publication on January 14, 2004; \\ presented by GeORGE A. DosReIs
}

\begin{abstract}
Leishmania amazonensis is the main agent of diffuse cutaneous leishmaniasis, a disease associated with anergic immune responses. In this study we show that the crude antigen of Leishmania amazonensis (LaAg) but not $L$. braziliensis promastigotes $(\mathrm{LbAg})$ contains substances that suppress mitogenic and spontaneous proliferative responses of $\mathrm{T}$ cells. The suppressive substances in $\mathrm{LaAg}$ are thermoresistant $\left(100^{\circ} \mathrm{C} / 1 \mathrm{~h}\right)$ and partially dependent on protease activity. T cell anergy was not due to a decreased production of growth factors as it was not reverted by addition of exogenous IL-2, IL-4, IFN- $\gamma$ or IL-12. LaAg did not inhibit anti-CD3-induced $\mathrm{T}$ cell activation, suggesting that anergy was due to a defect in antigen presentation. It was also not due to cell necrosis, but was accompanied by expressive DNA fragmentation in lymph node cells, indicative of apoptosis. Although pre-incubation of macrophages with LaAg prevented their capacity to present antigens, this effect was not due to apoptosis of the former. These results suggest that the $\mathrm{T}$ cell anergy found in diffuse leishmaniasis may be the result of parasite antigen-driven apoptosis of those cells following defective antigen presentation.
\end{abstract}

Key words: Leishmania, anergy, apoptosis.

\section{INTRODUCTION}

Leishmaniasis is a complex of diseases that affects over 12 million people in 88 countries, and may be caused by over 17 species of the protozoan parasite Leishmania (WHO 2002). The disease is transmitted by sandflies (Soares and Turco 2003), which inoculate the promastigote forms of the parasite into the skin during bloodmeal and these will in turn infect local and incoming macrophages. After transformation into amastigote forms inside the macrophage parasitophorus vacuoles, dermotropic parasite species will keep on infecting skin macrophages

Correspondence to: Bartira Rossi-Bergmann

E-mail: bartira@biof.ufrj.br at the site of the bite whereas viscerotropic species will migrate and infect liver, spleen and bone marrow macrophages. Cutaneous leishmaniasis is generally a benign and common form of the disease, but in some cases of L. braziliensis and L. amazonensis infections, the skin lesion may evolve into the dreadful mucosal or diffuse forms, respectively. Diffuse cutaneous leishmaniasis which is predominantly caused by $L$. amazonensis resembles lepromatous leprae, is characterized by absence of $T$ cells and delayed-type hypersensitivity responses and may persist for a lifetime (Convit et al. 1972, Castes and Tapia 1998). 
A great effort has been devoted to understanding the pathogenic mechanisms related to dysfunction of the immune system in leishmaniasis. In mice, it is widely accepted that the greater susceptibility of BALB/c mice to L. major infection is associated with TH2-type T cells which produce IL-4 and IL-10 whereas resistance by other mouse strains is associated with TH1-type cells which produce IFN-gamma (reviewed by Sacks and Noben-Trauth 2002). However, in L. amazonensis infection such dichotomy may not be so clear-cut. While C57Bl/10 mice are able to heal following infection with $L$. major, they fail to heal following infection with $L$. amazonensis due to the absence of a TH1 response (Afonso and Scott 1993). Little is known about the anergic mechanisms which determines the development of the diffuse form of cutaneous leishmaniasis in $L$. amazonensis infection, but TGF- $\beta$ may be a key cytokine since it is greatly increased in mice immunized with $L$. amazonensis but not with $L$. braziliensis antigens (Pinheiro et al. submitted). The anergic nature of $L$. amazonensis may be of relevance not only in the genesis of the diffuse form of the disease but also in the formulation of one of the most studied human vaccines (Abath 2000). Leishvacin ${ }^{\circledR}$ was previously composed of killed promastigotes of various parasite species (L. mexicana, L. amazonensis, L. guyanensis, and two L. major-like) but for standardization reasons L. amazonensis is now used as a sole component (Marzochi et al. 1998). Although the $L$. amazonensis vaccine may be immunogenic (De Luca et al. 2001), some individuals, possibly those who would develop the diffuse form of infection, are totally unresponsive.

Apoptosis of host $\mathrm{T}$ cells appears to be an important immunopathological feature of Trypanosoma cruzi (Lopes et al. 1995), Toxoplasma gondii (Liesenfeld et al. 1997), and Leishmania sp (Das et al. 1999, Bertho et al. 2000) infections. In this work we evaluate whether irrespective of an active infection $L$. amazonensis possess apoptosisrelated anergenic properties that would have implications in Leishvacin ${ }^{\circledR}$ inefficiency and in the diffuse form of the disease.

\section{MATERIALS AND METHODS}

Animals: BALB/c mice originally obtained from Jackson Laboratory (Bar Harbor, Maine) were bred and maintained at our own facilities using sterilized bedding, filtered water and pelleted food. Animals were used at 6 to 8 weeks of age in all experiments.

Parasites and antigens: For the preparation of antigens, L. amazonensis (IFLA/BR/67/PH8), and $L$. braziliensis (MHOM/BR/96/H3456) promastigotes were grown at $28^{\circ} \mathrm{C}$ in M199 medium (Cultilab, Brazil) containing $10 \%$ heat-inactivated fetal bovine serum (HIFCS, GIBCO Laboratories, Grand Island, N.Y). Stationary growth phase promastigotes were washed three times in phosphate buffered saline (PBS) in sterile conditions and concentration adjusted to $2 \times 10^{8}$ promastigotes $/ \mathrm{ml}$ in PBS. Parasite suspensions were submitted to five cycles of freezing and thawing and microscopically inspected for the absence of intact parasites. The antigens prepared as above (herein named LaAg and LbAg, respectively) were lyophilized, weighted, stored at $-20^{\circ} \mathrm{C}$ and reconstituted with PBS immediately before use. When appropriate, protein-enriched LaAg was prepared using protease inhibitors. Washed promastigotes were suspended in lysis buffer (20 mM Tris, pH8,0; $50 \mathrm{mM} \mathrm{NaCl,} 5 \mathrm{mM}$ DTT, $5 \mu \mathrm{m} \mathrm{ZnCl}_{2}, 1 \mathrm{mM}$ EDTA) containing $1 \mathrm{mM}$ PMSF, $30 \mu \mathrm{M}$ TLCK, $30 \mu \mathrm{M}$ TPCK, $10 \mu \mathrm{g} / \mathrm{ml}$ aprotinin, $10 \mu \mathrm{g} / \mathrm{ml}$ pepstatin A and $10 \mu \mathrm{g} / \mathrm{ml}$ leupeptin and ultrasonicated. The lysate was centrifuged first at $15.000 \times \mathrm{g} / 10 \mathrm{~min}$, the supernatant was recentrifuged at $120.000 \times \mathrm{g} / 80 \mathrm{~min} / 4^{\circ} \mathrm{C}$ and the soluble part precipitated under agitation at $4{ }^{\circ} \mathrm{C}$ with ammonium sulfate at $60 \%$ of saturation $(361 \mathrm{~g} / \mathrm{liter})$ in $\mathrm{pH}$ 7.0. After centrifugation, the supernatant was extensively dialyzed against distilled water and stored at $-20^{\circ} \mathrm{C}$. Lysis buffer with protease inhibitors, but without parasites, was treated in the same way as controls.

Infection: $\mathrm{BALB} / \mathrm{c}$ mice were infected in the right hind footpad with $2 \times 10^{6}$ stationary phase $L$. amazonensis promastigotes. 
Proliferation assay: Cells from inguinal nodes from normal or 7 day-infected BALB/c mice were stimulated in vitro with $5 \mu \mathrm{g} / \mathrm{ml}$ Concanavalin A (Sigma) or $0.5 \mu \mathrm{g} / \mathrm{ml}$ anti-CD3 (R\&D Systems) in the presence of different concentrations of $\mathrm{LaAg}$ for 48h. Alternatively, cells from infected mice were incubated for 2 hours in the presence of $50 \mathrm{U} / \mathrm{ml}$ IL-2, $100 \mathrm{U} / \mathrm{ml} \mathrm{IL-4,} 5 \mathrm{ng} / \mathrm{ml} \mathrm{IL-12}$ or $50 \mathrm{U} / \mathrm{ml}$ IFN- $\gamma$ (Pharmingen) prior to addition of $40 \mu \mathrm{g} / \mathrm{ml}$ $\mathrm{LaAg}$. The proliferative response was estimated by ${ }^{3} \mathrm{H}$-thymidine (Sigma, 0,5 $\mu \mathrm{Ci} /$ well) incorporation in the last 6 hours of culture. Cells were collected using a Dot-Blot apparatus (Rossi-Bergmann and Noleto 1994), and the radioactivity expressed as cpm.

Antigen presentation assay: Peritoneal cells from normal $\mathrm{BALB} / \mathrm{c}$ mice were cultured at $37^{\circ} \mathrm{C}$ and $4 \% \mathrm{CO}_{2}$ in Dulbecco-modified Minimum Essential Medium (D-MEM) at $4 \times 10^{5}$ cells/well a 96-well culture plate for adherence. The non-adherent cells were removed and $\mathrm{LaAg}$ was added at different concentrations in D-MEM with $10 \%$ HIFCS. After incubation for 17 hours, the cells were washed two times with PBS to remove free LaAg. Nylon woolpurified $\mathrm{T}$ cells from 7 day-infected BALB/c were added at $4 \times 10^{5}$ cells/well $(200 \mu \mathrm{l})$ to the adherent cells and the cultures incubated for a further 72 hours at $37^{\circ} \mathrm{C}$. The cell proliferation was assessed as described above.

Apoptosis: Lymph node cells $\left(2 \times 10^{6}\right)$ from infected BALB/c mice were incubated for $17 \mathrm{~h}$ in the presence of $\mathrm{LaAg}$ ( 40 and $400 \mu \mathrm{g} / \mathrm{ml}$ ) or $1 \mu \mathrm{M}$ dexamethasone. Cells were pelleted and lysed with $0.5 \%$ Triton X-100, $5 \mathrm{mM}$ Tris and $5 \mathrm{mM}$ EDTA $\mathrm{pH} 8,0$. After centrifugation $(30000 \mathrm{rpm} / 17 \mathrm{~min} /$ $10^{\circ} \mathrm{C}$ ), the DNA in the supernatants were extracted with phenol/chloroform and precipitated with isopropanol at $-20^{\circ} \mathrm{C} / 18 \mathrm{~h}$. Samples were treated with RNase and the DNA was air dried and reconstituted with TE buffer. The samples were submitted to electrophoresis in $1.8 \%$ agarose gels and the DNA was visualized under ultraviolet light after staining with ethidium bromide. Alternatively, adherent mouse peritoneal cells were incubated in triplicate in 24well culture plates for $6 \mathrm{~h}$ with $200 \mu \mathrm{g} / \mathrm{ml} \mathrm{LaAg}$ or
$1 \mu \mathrm{M}$ dexamethasone. Cells were then washed and incubated with AnnexinV - FITC (R\&D Systems) for $15 \mathrm{~min}$ at $37^{\circ} \mathrm{C}$ and the percentage of fluorescent cells counted under UV inverted microscopy at a minimum of 300 cells/well.

Statistical analysis: All experiments were reproduced at least twice and a representative experiment is shown. The statistical differences between two groups were determined by the Student's $t$ test, and were considered significant when $\mathrm{p} \leq 0.05$.

\section{RESULTS}

\section{LAAg INHIBITS the SPontaneous AND \\ Mitogenic Proliferation of Immune Cells}

The course of cutaneous leishmaniasis is determined by the immune response in the earlier days of infection (Scott 1996). To investigate the T cell response to LaAg during the course of infection, cells from inguinal nodes were taken at days $0,7,14$, 21 and 28 of infection with L. amazonensis and incubated for $48 \mathrm{~h}$ with varying concentrations of $\mathrm{LaAg}$ in the absence or the presence of the $\mathrm{T}$ cell mitogen Concanavalin A. The Fig. 1A shows that as disease progresses, the lymph node cells are increasingly activated and proliferate spontaneously in vitro. However, in the presence of $\mathrm{LaAg}(40 \mu \mathrm{g} / \mathrm{ml})$ the spontaneous proliferation is significantly abrogated in all time points. The observation that cells from uninfected mice (day 0 of infection) were also suppressed indicates the presence of unspecific suppressor substances in LaAg. Suppression was also observed in Concanavalin A-stimulated cells (Fig. 1B), where LaAg managed to decrease the mitogenic responses in a dose-dependent manner. T cell unresponsiveness was not a post-activation event, since kinetics studies starting at 9 hours and ending at 84 hours demonstrated lack of proliferation in response to $\mathrm{LaAg}$ at any time point (data not shown). The incapacity of $\mathrm{LaAg}$ to totally abrogate proliferation on day 21 of infection (Fig. 1B) was probably due to the higher state of intrinsic cell activation. Since antigen-specific unresponsiveness was seen throughout infection (Fig. 1A), and the earlier stages are normally critical to the outcome 

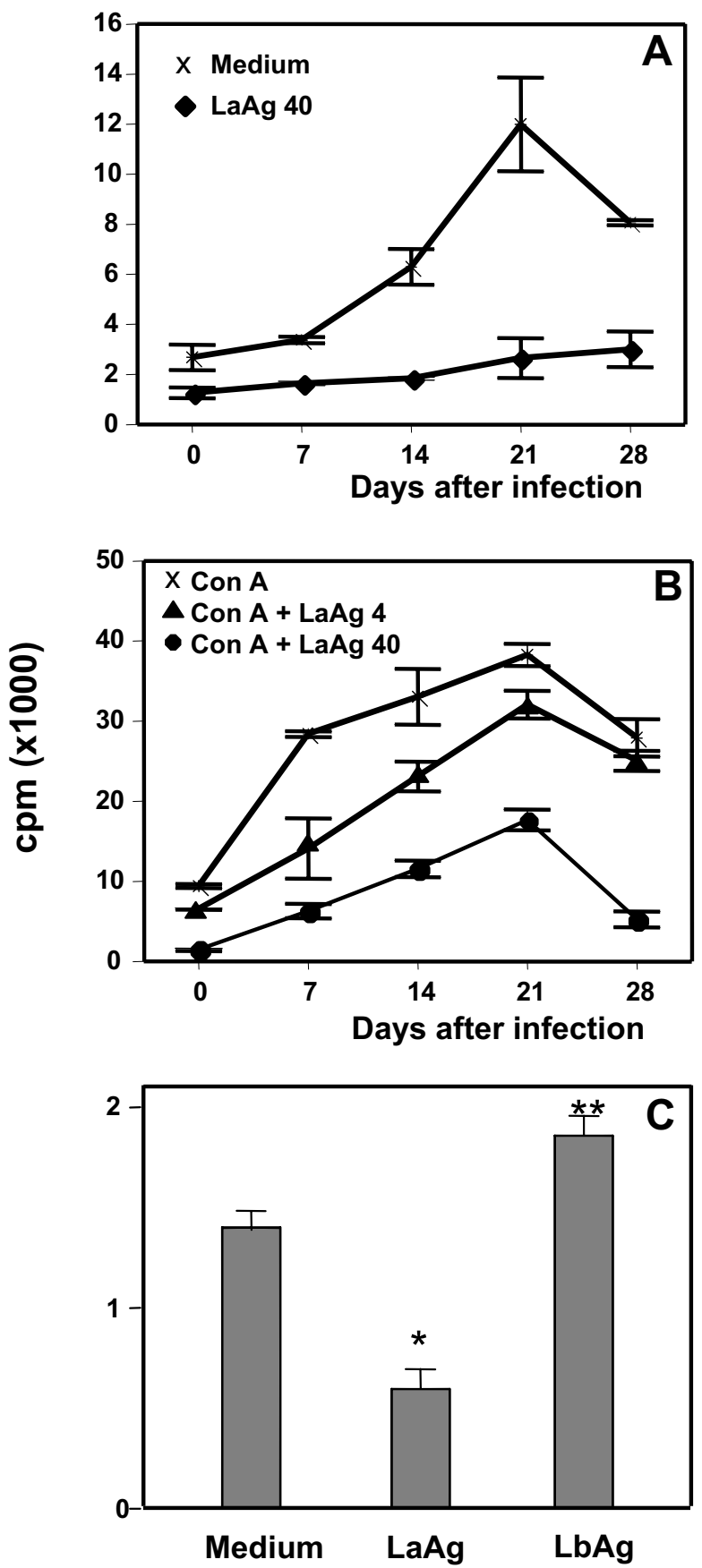

Fig. 1 - LaAg- induced suppression of cell proliferation during the course of infection. Groups of BALB/c mice at different times of infection with L. amazonensis were sacrificed and their lesion-draining lymph node cells obtained. The spontaneous (A) or Con A-induced proliferation (B) was measured in the presence of the indicated concentrations of $\mathrm{LaAg}$. In $(\mathrm{C})$, cells from 7-day infected mice were restimulated with $40 \mu \mathrm{g} / \mathrm{ml}$ of LaAg or LbAg. Mean $\pm \mathrm{SD}(\mathrm{n}=3)$. Asterisks indicate $(*) \mathrm{p} \leq 0.01$ and $(* *)$ $\mathrm{p} \leq 0.05$ in relation to control. 


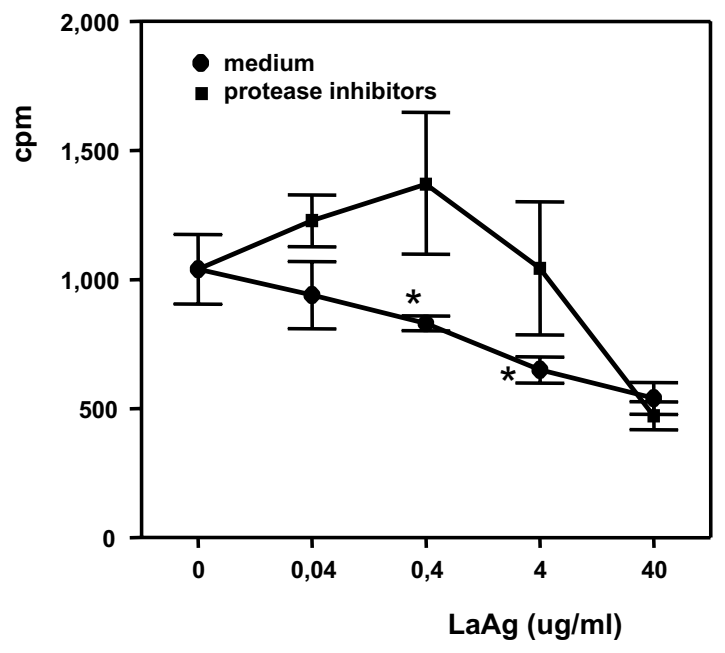

Fig. 2 - Effect of LaAg prepared with protease inhibitors on lymphocyte cell proliferation. Cells from 7 day-infected mice were incubated with different concentrations of LaAg prepared in the presence or absence of protease inhibitors for 72 hours as described in Materials and Methods. Mean \pm SD $(n=3)$. Asterisks indicate $\mathrm{p} \leq 0,01$ in relation to the same concentration point.

of the disease, we used cells at day 7 as sources of "immune" cells. We found that suppression is a L. amazonensis feature, since L. braziliensis antigens prepared in the same way were stimulatory (Fig. 1C). There is evidence that L. amazonensis has a greater amount of cytolytic proteins than other species, such as L. guyanensis (Almeida-Campos and Horta 2000). To determine if the inhibitory effect of LaAg was due to protease activity, the parasites were treated with a cocktail of protease inhibitors (PMSF, TLCK, TPCK, aprotinin, pepstatin and leupeptin) before and during antigen preparation. Figure 2 shows that the resulting protein-rich fraction of LaAg was also T-cell suppressive at concentrations of $\mathrm{LaAg}$ above $4 \mu \mathrm{g} / \mathrm{ml}$, but was devoid of activity at lower concentrations, indicating that the inhibitory effect of $\mathrm{LaAg}$ is partially dependent on protease activity.

\section{The Suppression Induced By the LaAg} IS NOT Due to THE LACK OF Key Cytokines

To evaluate if the T-cell suppression induced by $\mathrm{LaAg}$ could be reverted by the addition of exo- genous cytokines, lymph node cells from infected BALB/c mice were pre-incubated for 2 hours in the presence of IL-2, IL-4, IL-12 and IFN- $\gamma$ alone or in combination before the addition of $\mathrm{LaAg}$. The results expressed in Figure 3 show that in none of the conditions tested there was a reversion of the inhibitory effect, indicating that the anergy was not due to insufficient levels of lymphocyte growth/differentiation factors (IL-2, IL-4 or IL-12) or macrophage-activating cytokines (IFN- $\gamma$ ).

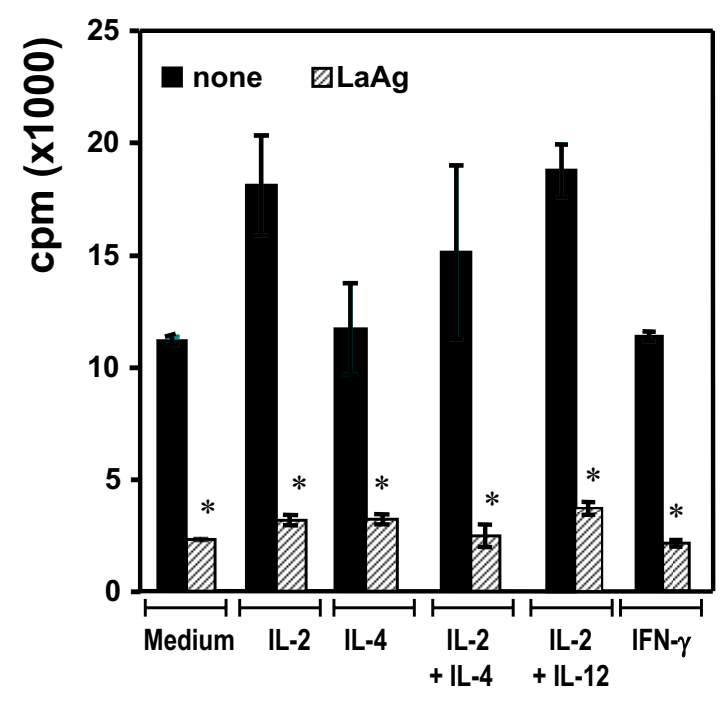

Fig. 3 - Inhibitory effect of $\mathrm{LaAg}$ in the presence of exogenous cytokines. Draining lymph node cells from 7-day-infected mice were cultured for 2 hours in the presence of IL-2 (100 U/ml), IL-4 (100 U/ml), IL-12 $(5 \mathrm{ng} / \mathrm{ml})$ and/or IFN- $\gamma$ alone or in combination as indicated. $40 \mu \mathrm{g} / \mathrm{ml} \mathrm{LaAg}$ was then added and cells were cultured at $37^{\circ} \mathrm{C} / 4 \% \mathrm{CO}_{2}$ for a further 46 hours. The proliferative response was expressed in cpm, as described in Materials and Methods. Mean \pm SD $(n=3)$. Asterisks indicate $\mathrm{p} \leq 0,01$.

\section{LaAg does not Inhibit the Cell \\ Proliferation INDUCED by ANTI-CD3}

The observation that the suppression induced by $\mathrm{LaAg}$ in vitro occurs in cells from both normal and infected animals (Fig. 1) suggested a lack of involvement of the TCR-CD3 complex. Figure 4 shows that unlike Concanavalin A-stimulation, LaAg does not inhibit the lymphocyte proliferation mediated by anti-CD3. Actually, this was increased 
in concentrations of LaAg between 0.4 and $4 \mu \mathrm{g} / \mathrm{ml}$. Stimulation with Concanavalin A requires antigen presentation by accessory cells such as macrophages (Holt et al. 1985). Thus, macrophages were pulsed with $\mathrm{LaAg}$ for 2 hours and after antigen removal, they were co-cultured with immune T cells. Figure 5 confirms that LaAg significantly affected the capacity of macrophages to process/present parasite antigens in a dose-dependent fashion.

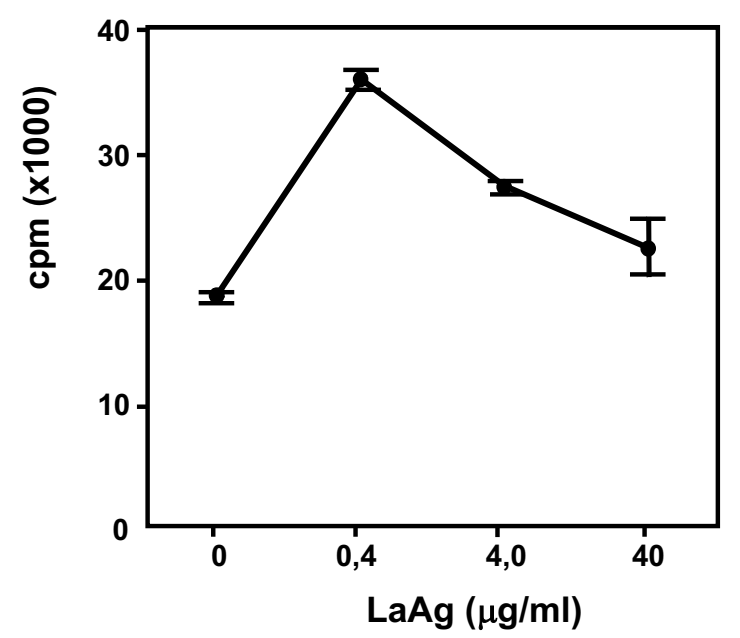

Fig. 4 - Effect of LaAg on anti-CD3-induced proliferation. Lymph node cells from 7-day infected mice were cultured in the presence of different $\mathrm{LaAg}$ concentrations for $1 \mathrm{~h}$. After this time, cells were transferred with $\mathrm{LaAg}$ to a 96-well plate adsorbed with anti-CD3. The proliferative response was measured 48 hours later. Mean $\pm \operatorname{SD}(n=3)$.

\section{LaAg Induces Apoptosis in Lymph Node Cells}

To investigate if antigen unresponsiveness was due to LaAg toxicity, we first evaluated cell death due to necrosis. However, significant release of lactate dehydrogenase or internalization of Trypan Blue dye used as indicators of cell lysis was achieved only with $\mathrm{LaAg}$ concentrations above $400 \mu \mathrm{g} / \mathrm{ml}$. This is well above the necessary to induce cell anergy (data not shown), indicating that necrosis was not the main mechanism. Electrophoresis of the DNA of cells pre-cultured with LaAg showed an increased DNA fragmentation (indicator of apoptosis), in relation to cells cultured without $\mathrm{LaAg}$ (Fig. 6A). DNA

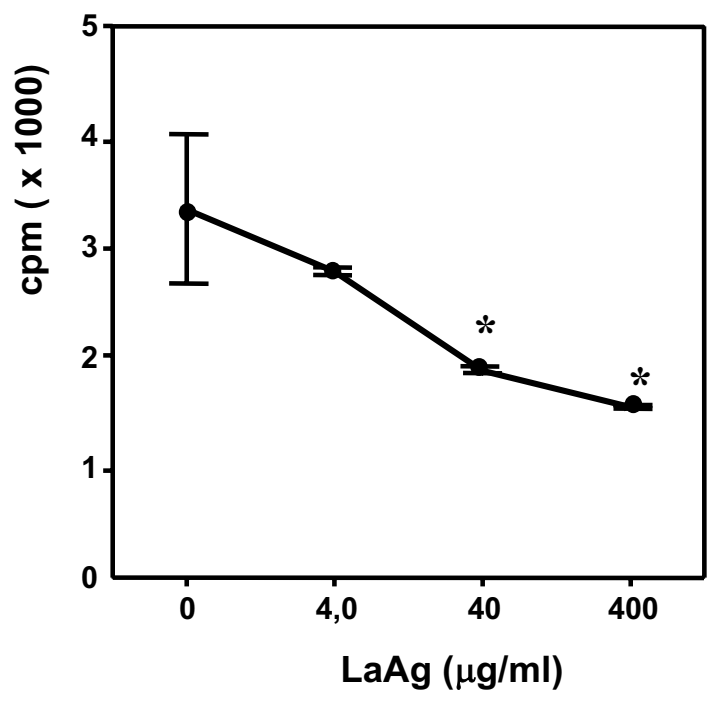

Fig. 5 - Effect of $\mathrm{LaAg}$ on antigen presentation. Peritoneal cells from normal BALB/c mice were cultured at $4 \times 10^{5}$ with $\mathrm{LaAg}$ at the indicated concentrations. Adherent cells were washed twice and then co-cultured for a further $72 \mathrm{~h}$ with $2 \times 10^{5}$ immune T cells. The cell proliferation was expressed as $\mathrm{cpm}$. Controls were $T$ cells incubated without adherent cells for the same time period: $301 \pm 85 \mathrm{cpm}$. Mean $\pm \mathrm{SD}(\mathrm{n}=3)$. Asterisks indicate $\mathrm{p} \leq 0,01$ in relation to $0 \mu \mathrm{g} / \mathrm{ml}$.

fragmentation was confirmed by the more quantitative TUNEL assay, where the percentage of cells with spontaneously fragmented DNA (20\%) was significantly increased to $48 \%$ when the cells were cultured in the presence of $40 \mu \mathrm{g} / \mathrm{ml} \mathrm{LaAg}$ (data not shown). The results above showed that the suppressive effect of $\mathrm{LaAg}$ was associated with apoptosis but not necrosis. The cell type undergoing apoptosis is not determined yet, but it is unlikely macrophages since incubation of adherent peritoneal cells with a supraoptimal concentration of $\mathrm{LaAg}(200 \mu \mathrm{g} / \mathrm{mL})$ for $8 \mathrm{~h}$ did not increase the percentage of cells expressing phosphatidylserine (Fig. 6B).

\section{DISCUSSION}

The immune regulation during cutaneous leishmaniasis is well described in the murine model of infection with L. major (Sacks and Noben-Trauth 2002). Less is known about the host-parasite relationship 


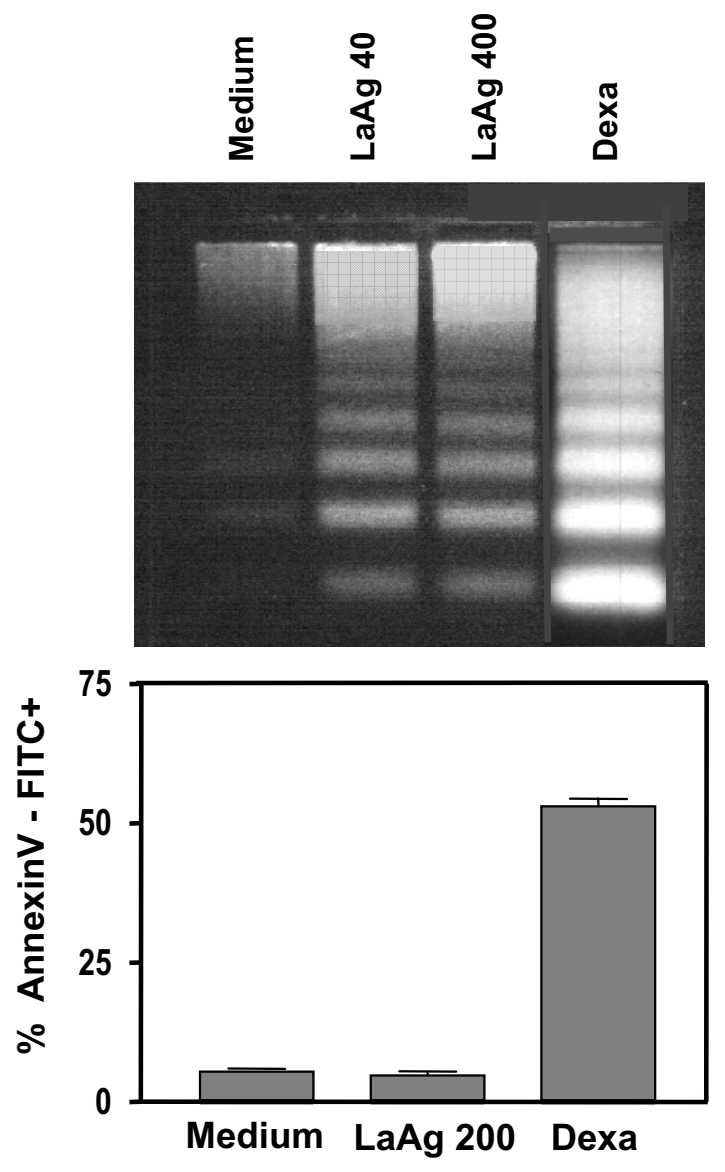

Fig. 6 - LaAg induces apoptosis in BALB/c mice infected cells. (A) Lymph node cells from L. amazonensis infected mice (day 7) were cultured for 17 hours in the presence of $\mathrm{LaAg}$ at 40 and $400 \mu \mathrm{g} / \mathrm{ml}$ or $1 \mu \mathrm{M}$ dexamethasone. The total cell DNA was extracted and submitted to electrophoresis in agarose gel as described. (B) Macrophages from normal BALB/c mice were incubated with $\mathrm{LaAg}$ at $200 \mu \mathrm{g} / \mathrm{ml}$ for 6 hours. Cells were incubated with AnnexinV-FITC for $15 \mathrm{~min} / 37^{\circ} \mathrm{C}$.

during infection with L. amazonensis. In the search for immunogenic molecules for vaccine development, various $L$. major antigens have been identified, such as the glycoprotein gp63, Hsp80, LACK, $1 \mathrm{G6}$ or 4H6 (WHO 2001). Earlier studies showed that the glycoprotein gp10/20 from L. amazonensis promastigotes stimulated the proliferative responses in vitro, but induced lesion exacerbation when used to immunize mice by s.c. or i.p. routes (Rodrigues et al. 1987). Recently, we showed that i.m. immunization with whole L. amazonensis antigens ( $\mathrm{LaAg}$ ), as used in the formulation of the vaccine Leishvacin ${ }^{\circledR}$ also promoted disease progression in $\mathrm{BALB} / \mathrm{c}$ mice infected with $L$. amazonensis in a manner associated with TGF- $\beta$ induction (Pinheiro et al. submitted). In the present study we demonstrate that $\mathrm{LaAg}$ not only is incapable to re-stimulate lymphocytes from infected animals in vitro but also renders murine $\mathrm{T}$ cells unable to proliferate in response to the mitogen Concanavalin A.

We found no evidence that $\mathrm{T}$ cell anergy was due to activation-induced death (Critchfield et al. 1994), as cells cultured with LaAg for shorter times ( 9 or 34 hours) showed no sign of proliferation (data not shown). Likewise, anergy does not seem to be due to lack of growth factors (Fig. 3) or to production of NO (Bingisser et al. 1998), as verified by the ineffectiveness of the NO synthase inhibitor NG-methyl-L-arginine added to the culture to revert anergy (data not shown).

It was previously shown that intracellular infection with $L$. amazonensis leads to increased production of TGF- $\beta$ by macrophages (Barral-Netto et al. 1992). We found that an active infection is not mandatory since culture with $\mathrm{LaAg}$ also greatly increases TGF- $\beta$ production (manuscript in preparation). TGF- $\beta$ is a cytokine with immunosuppressive and apoptotic properties. The nature of the TGF- $\beta$-inducing substance(s) in LaAg is unknown, but it is probably not a cystein protease such as the L. chagasi cathepsin B-like proteases (Gantt et al. 2003) since it was demonstrated to be thermoresistant $\left(100^{\circ} \mathrm{C} / 1 \mathrm{~h}\right.$, data not shown $)$ and $\mathrm{T}$-suppression was only partially affected by a cocktail of protease inhibitors (Fig. 2). We have observed that neutralization with anti-TGF- $\beta$ antibodies restored the T cell responsiveness to $\mathrm{LaAg}$ (Pinheiro et al. submitted). Thus, it is likely that TGF- $\beta$ production by macrophages is a primary key event in T cell apoptosis/anergy induced by LaAg but the contribution of TGF- $\beta$ released by the apoptotic T cells (Chen et al. 2001), membrane-bound TGF- $\beta$ in CD4+CD25+ regulatory $\mathrm{T}$ cells (Nakamura et al. 2001) or the unbalance between CTLA- 4 and CD28 expression 
on CD4+ cells (Gomes and DosReis 2001, Sung et al. 2003) should also be considered. Isolated immune $\mathrm{T}$ cells were suppressed when co-cultured with LaAg-pulsed macrophages (Fig. 5). Once defective antigen presentation was extended to unrelated antigens, as observed by the impaired capacity of macrophages pre-pulsed with $40 \mu \mathrm{g} / \mathrm{mL} \mathrm{LaAg}$ to present OVA to a TCR-specific DO-11.10 hybridoma (data not shown), it seems likely that the anergic effect of $\mathrm{LaAg}$ is primarily on APCs rather than on the induction of regulatory $\mathrm{T}$ cells during leishmanial infection (Belkaid et al. 2002).

The cell type(s) in the mixed lymph node cells undergoing apoptosis (Fig. 6, top) were not phenotypically identified here, but they are unlikely adherent APCs as isolated macrophages remained annexin $\mathrm{V}$ negative when cultured with supraoptimal concentrations of LaAg (Fig. 6, bottom). The finding that LaAg did not suppress and actually transiently increased T cell responses to anti-CD3 - a TCR-driven APC-independent stimulus (Fig 4) - further corroborates that $\mathrm{LaAg} \mathrm{T}$ suppression is due to impaired antigen processing/presentation.

In summary, this study suggests that L. amazonensis antigens induce unresponsiveness to both related and unrelated antigens by a mechanism possibly initiated by TGF- $\beta$ production by macrophages and culminated with $\mathrm{T}$ cell apoptosis. These findings may contribute to a better understanding of the anergic mechanisms associated with diffuse cutaneous leishmaniasis and propose that the use of LaAg as the sole antigen in Leishvacin ${ }^{\circledR}$ should be reconsidered.

\section{RESUMO}

A Leishmania amazonensis é o principal agente etiológico da leishmaniose cutânea difusa, uma doença associada a respostas imunes anérgicas. Neste estudo nós mostramos que o extrato bruto de promastigotas de Leishmania amazonensis (LaAg), mas não de L. braziliensis (LbAg), contém substâncias que suprimem respostas proliferativas, espontâneas e mitogênicas, de células T. As substâncias supressoras no LaAg são termo-resistentes $\left(100^{\circ} \mathrm{C} / 1 \mathrm{~h}\right)$ e parcialmente dependentes da atividade de proteases. A anergia de células T não foi devida à diminuição na produção de fatores de crescimento, uma vez que não foi revertida pela adição de: IL-2, IL-4, IFN- $\gamma$ ou IL-12. O LaAg não inibiu a ativação de células T induzida por antiCD3, sugerindo que a anergia é devida a um defeito na apresentação de antígenos. A anergia não foi devida à necrose celular, mas foi acompanhada de uma expressiva fragmentação de DNA nas células de linfonodos, indicativo de apoptose. Apesar da pré-incubação de macrófagos com LaAg ter inibido sua capacidade de apresentação de antigenos, este efeito não foi devido à apoptose dos primeiros. Estes resultados sugerem que a anergia de células $\mathrm{T}$ encontrada na leishmaniose difusa deve ser devida à apoptose dessas células que se segue à apresentação defeituosa de antígenos pelo antígeno do parasito.

Palavras-chave: Leishmania, anergia, apoptose.

\section{REFERENCES}

Аватн FGC. 2000. Development of vaccines against human parasitic diseases: tools, current status and perspectives. Expert Opin Invest Drugs 9: 301-310.

Afonso LCC AND ScotT P. 1993. Immune responses associated with susceptibility of $\mathrm{C} 57 \mathrm{B1} / 10$ mice to Leishmania amazonensis. Infect Immun 61: 29522959.

Almeida-Campos FR and Horta MF. 2000. Proteolytic activation of leishporin: evidence that Leishmania amazonensis and Leishmania guyanensis have distinct inactive forms. Mol Biochem Parasitol 111: 363-375.

Barral-Netto M, Barral A, Brownell CE, Skeiky YAW, Ellingsworth LR, TwARDZik DR AND REED SG. 1992. Transforming Growth-Factor-Beta In Leishmanial Infection - A Parasite Escape Mechanism. Science 257: 545-548.

Belkaid Y, Piccirillo CA, Mendez S, Shevach EM AND SACKs DL. 2002. CD4(+)CD25(+) regulatory T cells control Leishmania major persistence and immunity. Nature 420: 502-507.

Bertho AL, Santiago MA, Da Cruz AM and CouTINHO SG. 2000. Detection of early apoptosis and cell death in T CD4+ and CD8+ cells from lesions of patients with localized cutaneous leishmaniasis. Braz J of Med and Biol Res 33: 317-325.

Bingisser RM, Tilbrook PA, Holt PG and Kees UR. 1998. Macrophage-derived nitric oxide regulates $\mathrm{T}$ 
cell activation via reversible disruption of the Jak3/ STAT5 signaling pathway. J Immunol 160: 57295734.

Castes M And TAPIA FJ. 1998. Immunopathology of an tegumentary leishmaniasis. Acta Cient Venez 49: 42-56.

Chen WJ, Frank ME, Jin WW and Wahl SM. 2001. TGF-beta released by apoptotic $\mathrm{T}$ cells contributes to an immunosuppressive milieu. Immunity 14 : $715-725$

Convit J, Rondon AJ and Pinardi ME. 1972. Diffuse cutaneous leishmaniasis - disease due to an immunological defect of host. Tr Roy Soc Trop Med Hyg 66: 603-608.

Critchfield JM, Racke MK, Zúñiga-Pflucker JC, Cannella B, Raine CS, Goverman J and LenaRDo MJ. 1994. T cell deletion in high antigen dose therapy of autoimmune encephalomyelitis. Science 263: 1139-1143.

Das G, Vohra H, Rao K, Saha B and Mishra GC. 1999. Leishmania donovani infection of a susceptible host results in CD4+ T-cell apoptosis and decreased Th1 cytokine production. Scand J Immunol 49: 307-310.

de Luca PM, Mayrink W, Pinto JA, Coutinho SG, Santiago MA, Toledo VP, Costa CA, Genaro O, Reis AB and Mendonca SCF. 2001. A randomized double-blind placebo-controlled trial to evaluate the immunogenicity of a candidate vaccine against American tegumentary leishmaniasis. Acta Trop 80: 251-260

Gantt KR, Schultz-Cherry S, Rodriguez N, Jeronimo SMB, Nascimento ET, Goldman TL, Recker TJ, Miller MA and Wilson ME. 2003. Activation of TGF-beta by Leishmania chagasi: Importance for parasite survival in macrophages. J Immunol 170: 2613-2620.

Gomes NA AND DosReis GA. 2001. The dual role of CTLA-4 in Leishmania infection. Trends Parasitol 17: 487-491.

Holt PG, Degebrodt A, O'Leary C, Krska K and Plozza T. 1985. T cell activation by antigen presenting cells from lung tissue digests: suppression by endogenous macrophages. Clin Exp Immunol 62: 586-593.

Liesenfeld O, Kosec JC and Suzuki Y. 1997. Gamma interferon induces Fas-dependent apoptosis of Peyer's patch $\mathrm{T}$ cells in mice following peroral infection with Toxoplasma gondii. Infect Immun 65: $4682-$ 4689.

Lopes MF, da Veiga VF, SAntos AR, Fonseca ME And DosReis GA. 1995. Activation induced CD4+ T cell death by apoptosis in experimental Chagas' Disease. J Immunol 154: 744-752.

Marzochi KB, Marzochi MA, Silva AF, Grativol N, Duarte R, Confort EM and Modabber F. 1998. Phase 1 study of an inactivated vaccine against American tegumentary leishmaniasis in normal volunteers in Brazil. Mem Inst Oswaldo Cruz 93: 205-212.

Nakamura K, Kitani A and Strober W. 2001. Cell contact-dependent immunosuppression by CD4(+) $\mathrm{CD} 25(+)$ regulatory $\mathrm{T}$ cells is mediated by cell surface-bound transforming growth factor beta. J Exp Med 194: 629-644.

Rodrigues MM, Mendonça-Previato L, Charlab R AND BARCINSKI M. 1987. The cellular immuneresponse to a purified antigen from Leishmania mexicana subsp amazonensis enhances the size of the leishmanial lesion on susceptible mice. Infect Immun 55: 3142-3148.

Rossi-Bergmann B and Noleto G. 1994. A low-cost and efficient procedure for havesting DNA-labeled cells using a Dot-blot apparatus. Biotechniques 17: 678-680.

Sacks D and Noben-Trauth N. 2002. The immunology of susceptibility and resistance to Leishmania major in mice. Nature Rev Immunol 2: 845-858.

ScotT P. 1996. Th cell development and regulation in experimental cutaneous leishmaniasis. Chemical Immunol 63: 98-101.

SOARES RPP AND TURCo SJ. 2003. Lutzomya longipalpis (Díptera: Psychodidae: Phlebotominae): a review. An Acad Bras Cienc 75: 301-330.

Sung JL, Lin JT and Gorham JD. 2003. CD28 co-stimulation regulates the effect of transforming growth factor-beta 1 on the proliferation of naive CD4(+) T cells. Int Immunopharmacol 3: 233-245.

World Health Organization. 2001. Report of the TDR/IDRI Meeting on second-generation vaccines against leishmaniasis. 2001: 1-13.

World Health Organization. 2002. Annex 3: Burden of disease in DALYs by cause, sex and mortality stratum in WHO regions, estimates for 2001. The World Health report. Geneva: WHO 2002: 192-197. 